prediction of episodes of major depression: a replication. Arch Gen Psychiatry 2005; 62: 529-35.

40 Kaufman J, Yang BZ, Douglas-Palumberi H. Social supports and serotonin transporter gene moderate depression in maltreated children. Proc Natl Acad Sci USA 2004; 101: 17316-21.

41 Jacobs N, Kenis G, Peeters, Derom C, Vlietinck R, van Os J. Stress-related negative affectivity and genetically altered serotonin transporter function: evidence of synergism in shaping risk of depression. Arch Gen Psychiatry 2006; 63: 989-96.

42 Zalsman G, Huang Y, Oquendo MA, Burke AK, Hu XZ, Brent DA, Ellis SP, Goldman D, Mann JJ. Association of a triallelic serotonin transporter gene promoter region (5-HTTLPR) polymorphism with stressful life events and severity of depression. Am J Psychiatry 2006; 163: 1588-93.

43 Wilhelm K, Mitchell PB, Niven H, Finch A, Wedgwood L, Scimone A, Blair IP, Parker G, Schofield PR. Life events, first depression onset and the serotonin transporter gene. Br J Psychiatry 2006; 188: 210-5.
44 Cervilla J, Molina E, Rivera M, Torres-González F, Bellón JA, Moreno B, Luna JD, Lorente JA, Mayoral F, King M, Nazareth I. The risk for depression conferred by stressful life events is modified by variations at the serotonin transporter 5HTTLPR genotype: evidence from the Spanish PREDICT Gene cohort. Mol Psychiatry 2007; 12: 748-55.

45 Sun HS, Tsai HW, Ko HC, Chang FM, Yeh TL. Association of tryptophan hydroxylase gene polymorphism with depression, anxiety and comorbid depression and anxiety in a population-based sample of postpartum Taiwanese women. Genes Brain Behav 2004; 3: 328-36.

46 Coyle N, Jones I, Robertson E, Lendon C, Craddock N. Variation at the serotonin transporter gene influences susceptibility to bipolar affective puerperal psychosis. Lancet 2000; 356: 1490-1.

47 Scheid JM, Holzman CB, Jones N, Friderici KH, Nummy KA, Symonds Sikorskii A, Regier MK, Fisher R. Depressive symptoms in mid-pregnancy, lifetime stressors and the 5-HTTLPR genotype. Genes Brain Behav 2007; 6 : $453-64$.

case report

\title{
A case of male anorexia with Klinefelter's syndrome, 22 years later
}

\section{Christopher Paul Szabo}

In 1986 the British Journal of Psychiatry published a report 'A case of anorexia nervosa with Klinefelter's syndrome' (Hindler CG, Norris, DL. Br J Psychiatry, 149: 659-660). The case was of interest as it was the first documented case of anorexia nervosa in a male associated with Klinefelter's syndrome. The patient had initially been diagnosed as having 'atypical anorexia nervosa' and the Klinefelter's syndrome was cytogenetically proven. No other associated organic pathology was diagnosed at that time. Specifically, computed tomography (CT) scans were reported within normal limits.

Clinically, the patient had presented (in 1985) with significant weight loss, from $50 \mathrm{~kg}$ to $39.9 \mathrm{~kg}$ over the preceding 2 years. He had a history of prior admission to the unit (7 years earlier, at the age of 13) with a diagnosis of anorexia nervosa. In addition to the weight loss, he reported vomiting five times per week in the 2 months before the admission, but not as a consequence of binge eating or guilt following perceived overeating. The vomiting was not self-induced. The patient denied any fear of fatness, reporting a loss of appetite, excessive fluid intake and persistently feeling cold (features not inconsistent with anorexia nervosa). His limb length, sexual characteristics and delayed puberty suggested he had Klinefelter's syndrome.

Following the admission in 1985, a magnetic resonance image (MRI) scan was undertaken due to the onset of an ataxic gait, tremor and noticeable nystagmus. A cerebellar tumour was diagnosed, identified as an 'atypical teratoma' during a subsequent neurosurgery. Because of local infiltration and incomplete tumour excision, a course of radiotherapy followed the surgery. Thereafter, the patient gained $5.5 \mathrm{~kg}$ over the first 3 months and a further $3.5 \mathrm{~kg}$ in the next 6 months to weigh $51 \mathrm{~kg}$. His recovery was generally satisfactory. However, in January 1988 his speech began to slur and he became uncoordinated. A CT scan revealed a tumour in the right frontal lobe. Following surgery (with adjuvant radiotherapy), a germinoma was diagnosed. Review of the pathology findings concluded that both tumours had indeed been germinomas.

Between 1988 and 2000 a number of MRI scans did not reveal any recurrent tumour growth. The patient's last gadolinium-enhanced MRI scan (2005) showed no evidence of tumour recurrence in either the right frontal lobe or posterior fossa, and generalised cerebral and cerebellar involutional changes, possibly secondary to previous radiotherapy. At the most recent consultation (2006), the patient reported no eatingrelated concerns and he had no symptoms of an eating disorder.

Given that both tumours (frontal and cerebellar) were diagnosed as germinomas, it may be that although the cerebellar tumour had been the one initially diagnosed, the one in the frontal lobe had been there all along. With hindsight it appears possible that the initial clinical features were more harbingers of the pathology that was ultimately diagnosed, rather than of an eating disorder. Features of a developing neurological disturbance were noted during the various admissions to the eating disorders unit. However, they were not as prominent as the weight loss and vomiting which, together with the diagnosis of Klinefelter's syndrome and the initial negative CT scans, may have deflected attention. The reported absence of the more complex features of psychopathology usually associated with an eating disorder further suggests a more likely primarily neurological pathology in evolution.

The case highlights a specific clinical issue - the clinical interpretation of disordered eating and the distinction of such behaviour from an eating disorder.

Christopher Paul Szabo, University of the Witwatersrand, Division of Psychiatry, Faculty of Health Sciences, 7 York Rd, Parktown 2193, Johannesburg, South Africa. Email: Christopher.szabo@wits.ac.za 